Article

\title{
Towards Responsible Steel: Preliminary Insights
}

\section{Suzanne Benn ${ }^{1, *}$, Damien Giurco ${ }^{2}$, Paul James Brown ${ }^{1}$ and Renu Agarwal ${ }^{1}$}

1 UTS Business School, University of Technology, Sydney, P.O. Box 123, Broadway, NSW 2007, Australia; E-Mails: paul.j.brown@uts.edu.au (P.J.B.); renu.agarwal@uts.edu.au (R.A.)

2 Institute for Sustainable Futures, University of Technology, Sydney, P.O. Box 123, Broadway, NSW 2007, Australia; E-Mail: damien.giurco@uts.edu.au

* Author to whom correspondence should be addressed; E-Mail: suzanne.benn@uts.edu.au; Tel.: +61-2-9514-3060; Fax: +61-2-9514-3503.

Received: 9 December 2013; in revised form: 14 February 2014 / Accepted: 21 February 2014 / Published: 10 March 2014

\begin{abstract}
This paper examines the structures and processes underpinning the attempt of the Australian steel industry to establish a certification scheme for Responsible Steel. We take it as a case example of how collective action and collaboration along a supply chain has the potential to be a win-win situation for the environment and for the competitiveness of an industry sector. The paper identifies the drivers that have prompted key stakeholders from all major sectors of the Australian steel product life cycle from mining through steel manufacturing, processing, product fabrication, use and re-use, and recycling to collaborate in the establishment of the Steel Stewardship Forum (SSF), the structure established to lead the development of the certification scheme. The development of this initiative is indicative of the wider shift to sustainability-related certification schemes as a means of garnering legitimacy and market advantage and provides detailed insights into both the drivers for and the challenges associated with such initiatives. Findings from the paper contribute to our understanding of the shift to sustainable supply chains as it is interpreted through institutional and institutional entrepreneurship theory.
\end{abstract}

Keywords: sustainable supply chain; stewardship; institutional theory 


\section{Introduction}

This paper examines the structures and processes underpinning the current attempt of the Australian steel industry to establish a certification scheme for Responsible Steel. We use the example of the Steel Stewardship Forum (SSF), the body formed to "develop steel stewardship in Australia and a certification scheme across the entire steel supply chain" [1] as a case example of how collective action and collaboration across a supply chain or network has the potential to be a win-win situation for the sustainability and for the competitiveness of an industry sector. It provides a useful illustration of how companies, government, non-governmental organizations (NGOs) and industry associations can collaborate across supply networks to develop the tools essential to progressing sustainable development. The importance of such work in contributing to understanding environmental impacts across the whole life cycle of a material or product is illustrated by a recent report [2] finding that nearly half of companies surveyed do not engage with their supply chain on emissions or climate change, with the majority of emissions from value chains not currently measured.

\section{Phase Model of Sustainability}

Organizations alone cannot achieve sustainability and are dependent upon their relationships with their suppliers to improve their environmental, social and economic performance. Recent research on supply chain management has focused on sustainable supply chain management (SSCM) practices, and there is now a wide literature on the topic (e.g., [3,4]). Driven through rapid technological development, SSCM now encompasses communication and material flows that occur across loosely connected supply networks, as well as the more traditional linear, contractually based chains. Collaboration and connectivity are crucial in ensuring sustainable outcomes for organizations involved in these networks.

Seuring \& Muller ([5] on Page 1700) define SSCM practices as:

"the management of material, information and capital flows as well as cooperation among companies along the supply chain while taking goals from all three dimensions of sustainable development, i.e., economic, environmental and social, into account which are derived from customer and stakeholder requirements".

In understanding how organizations might shift their supply operations towards SSCM, we look to the sustainability phase model as set out in Figure 1.

This model builds on earlier environmental sustainability phase models [6] by incorporating elements of human sustainability, referring to capabilities such as stakeholder interaction and community relations (see also [7-9] for descriptions of other phase models). The model is designed as a tool for making meaningful comparisons between organizations to assess their current commitment to and practice of behaviors relevant to sustainability. The phases outline a set of distinct steps organizations may take in progressing to sustainability. There is a progression from active antagonism, through indifference, to a strong commitment to actively furthering sustainability values, within the organization and more widely across industry sectors and society as a whole [10]. SSCM is increasingly recognized as crucial to the strategic phase where organizations are proactively engaging across their supply networks to ensure sustainability is embedded in their business model. A key 
criterion for organizations if they are to reach this phase is to ensure that all relationships across the supply chain or network contribute to the sustainability strategy [11]. Such an outcome entails an emphasis on transparency and certification. The next section sets the context for our case example by explaining how this strategic approach to SSCM is playing out in relation to metals.

Figure 1. Sustainability phase model [11]. Reprinted/Reproduced with permission from Benn, Dunphy and Griffiths, 2014.

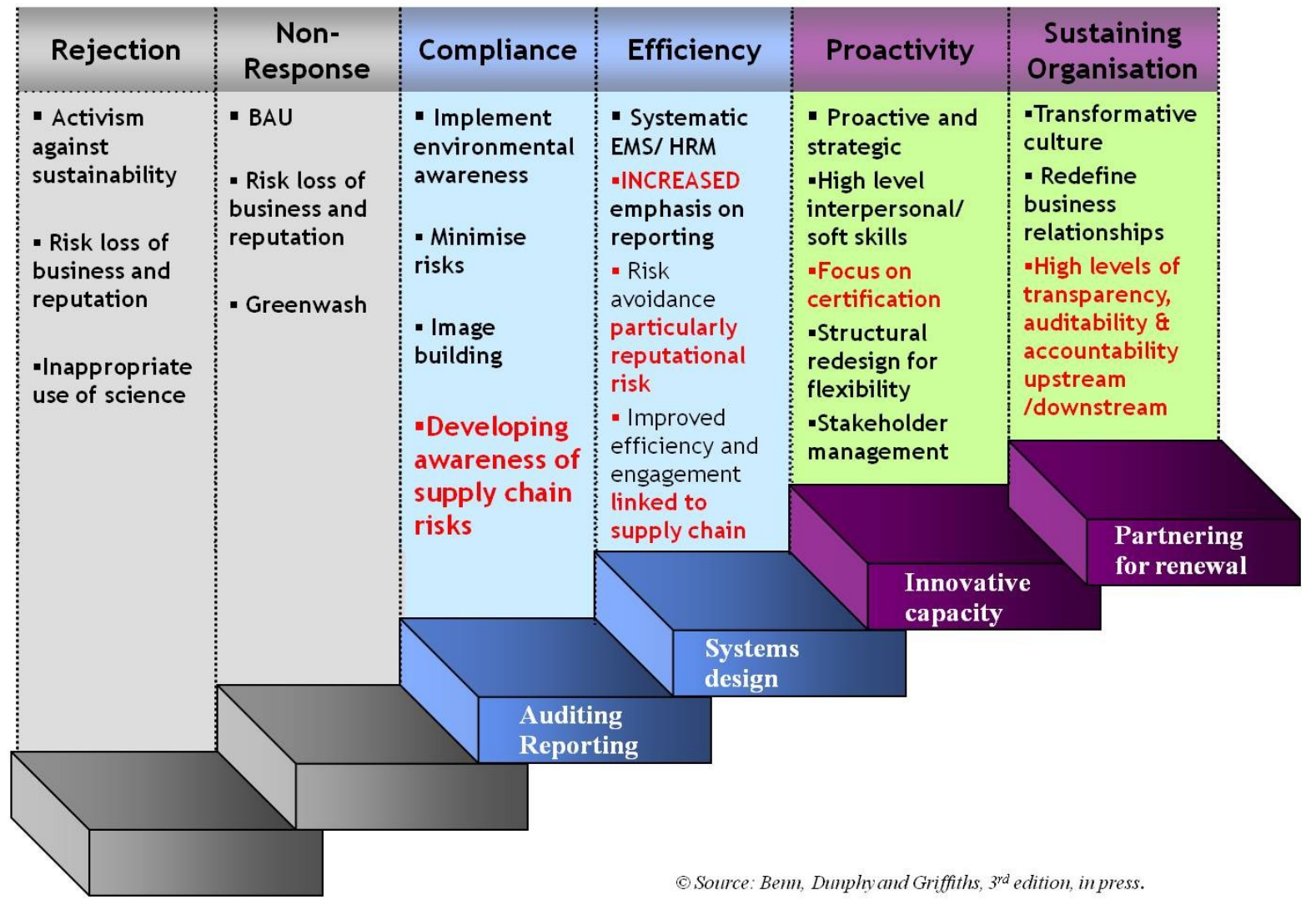

\section{International Drivers for Sustainability Certification}

This section outlines the rise in sustainability certification systems for metals and drivers for these schemes from the perspectives of producers and consumers. The certification of metals as commodities follows a trend of other soft commodities such as palm oil, timber and seafood. Drivers are discussed with respect to the phase model of corporate sustainability described in Section 2 and the specific case of the SSF is outlined in Section 4.

\subsection{Overview of Sustainability Certification Schemes for Metals}

An overview of certification schemes for metals is given in Table 1. They have arisen over the past five years with a view to both minimizing impacts and risks (the "non-response" and "compliance") steps in the phase model - for example the Dodd-Frank Act and "No Dirty Gold". Recently, other schemes have begun moving towards "competitive advantage" and "value creation", for example Responsible Jewelry Council and SSF-described in more detail in Section 4. This opportunity for value creation arises through, for example, European consumers being willing to pay higher prices for responsibly 
produced goods such as electronics [12]. A moderating influence on the potential for additional value creation is that global demand is now driven by consumers in developing countries who currently do not have the same preferences, for example in China cost and product safety are high priorities [13].

\subsection{Overview of Sustainable Supply Chain Drivers: Producers}

With respect to the sustainability phase model — managing risk (voluntarily) is a significant driver. For miners, this is connected with maintaining their social license to operate [14]. Disruptions to social license can occur from protests arising over controversial new mines or in existing operations from changes to worker conditions or from toxic releases to the environment. Whereas this was once the main domain of risk, namely, on-site, there is now an emerging phenomenon of "social license to market", namely that some markets will close off unless good practice can be demonstrated right along the supply chain.

The second driver is regulation and this has only appeared in any meaningful form since the passing of the Dodd-Frank Act in 2010 in the USA. It requires that companies subject to the USA Securities and Exchange Commission declare if any cassiterite minerals (which contain tin), wolframite (which contains tungsten), coltan (tantalum) and gold have been sourced from the Democratic Republic of the Congo (DRC). This law was designed to avoid conflict minerals, but has been criticized for unintended consequences of putting many miners out of work and doing little to improve the lives of the Congalese, despite ending the trade in conflict minerals [15].

Thirdly, some certification schemes, such as the Responsible Steel certification scheme described below, are being proposed in order to be strategic and pro-active in order to secure competitive advantage. This is done by showing that participants in the scheme are thinking holistically about the impacts on the environment and communities and are prepared to be more transparent with their reporting, not only to maintain access to existing markets, but in some cases to seek to attract a premium price or gain entry to premium markets (e.g., green buildings).

\subsection{Overview of Sustainable Supply Chain Drivers: Sustainable Procurement}

As a policy objective, sustainable procurement is a key means of attaining sustainable development. While there is some evidence that individual consumers are increasingly purchasing environmental or socially responsible goods [16], it is public sector and business to business purchasing that has the most potential to drive change. Organizations across all sectors procure goods and services on a far greater scale, exerting an "increasingly powerful influence on the economy and society" [17] (p. 207). In the building and construction industry, for example, policies concerning green public procurement that include requirements for life cycle analysis criteria appear to be a promising means of reducing the negative environmental impacts of materials used in this industry [18]. Collectively and individually, organizations are in a commanding position to contribute towards the sustainable use of resources through their procurement choices.

The mounting pressure to incorporate SSCM into their business model comes from various stakeholder groups such as customers, shareholders, executive boards, employees, governments and NGOs [19]. Numerous examples now exist where organizations and their related supply chains have introduced green and socially responsible products and services as a result of such pressures (e.g., [4]). 
Table 1. Supply chain certification and responsible supply chain schemes (adapted from [20]).

\begin{tabular}{|c|c|c|c|}
\hline Scheme (Year) & Origin & Focus & Description [Reference] \\
\hline $\begin{array}{l}\text { Dodd-Frank Act } \\
\text { (2010 Regulation) }\end{array}$ & USA Government & Companies & $\begin{array}{l}\text { Regulation regarding conflict minerals from Democratic Republic of the Congo (DRC) (cassiterite, wolframite, } \\
\text { coltan and gold). Companies subject to the USA Securities and Exchange Commission are required to disclose } \\
\text { whether above minerals used in their products originate from DRC or surrounding countries [21]. }\end{array}$ \\
\hline $\begin{array}{l}\text { Conflict Free Smelters (CFS) } \\
\text { (Est.2008, certifying) }\end{array}$ & $\begin{array}{l}\text { Global electronics } \\
\text { industry, GeSi, EICC }\end{array}$ & $\begin{array}{l}\text { Smelters supplying global electronics } \\
\text { industry with tantalum, tin, tungsten } \\
\text { and gold }\end{array}$ & $\begin{array}{l}\text { "The CFS is a voluntary program in which an independent third party evaluates smelter and refiner procurement } \\
\text { activities and determines if the smelter or refiner demonstrated that all the materials they processed originated } \\
\text { from conflict-free sources. The program aims to enable companies to source conflict-free minerals" [22]. }\end{array}$ \\
\hline $\begin{array}{l}\text { Fairtrade/Fairmined (Est 2006, } \\
\text { Certification from 2010) }\end{array}$ & $\begin{array}{c}\text { Alliance for Responsible } \\
\text { Mining/Fairtrade International }\end{array}$ & $\begin{array}{c}\text { Supporting Artisanal and } \\
\text { small scale miners since } 2010\end{array}$ & $\begin{array}{l}\text { Voluntary certification of small-scale miners. Final sellers of gold receive Fairtrade symbol. Currently being } \\
\text { phased out in favor of more flexible model [23]. }\end{array}$ \\
\hline No dirty gold (not certifying) & USA & $\begin{array}{l}\text { Community awareness to pressure USA } \\
\text { retailers (e.g., Macy's) to avoid dirty gold. }\end{array}$ & Public awareness website [24]. \\
\hline $\begin{array}{l}\text { Responsible steel } \\
\text { (planning certification) }\end{array}$ & Australia & All companies in supply chain & $\begin{array}{l}\text { The Steel Stewardship Forum (SSF) brings together the steel product life cycle-from mining through to } \\
\text { steel manufacturing, processing, product fabrication, use and re-use, and recycling —in the shared } \\
\text { responsibility of working together to minimizing the impact on society and the environment. It aims to be } \\
\text { presented at the Asia-Pacific Economic Cooperation (APEC) Mining Ministers Forum as a 'best practice' } \\
\text { model for the region [25]. }\end{array}$ \\
\hline $\begin{array}{l}\text { Responsible Jewellery Council } \\
\text { (Est. 2005; Chain of Custody } \\
\text { Certification in 2012) }\end{array}$ & International & $\begin{array}{l}\text { Companies along jewelry supply } \\
\text { chain (ISEAL member; also has } \\
\text { chain-of-custody standards) }\end{array}$ & $\begin{array}{l}\text { "The Responsible Jewellery Council is a not-for-profit, standards setting and certification organisation. It has } \\
\text { more than } 440 \text { member companies that span the jewellery supply chain from mine to retail". "The Code of } \\
\text { Practices addresses human rights, labour rights, environmental impact, mining practices, product disclosure } \\
\text { and many more important topics in the jewellery supply chain" [26]. }\end{array}$ \\
\hline $\begin{array}{l}\text { Initiative for Responsible Mining } \\
\text { Assurance (IRMA) (Est. 2006; } \\
\text { Certification planned in 2015) }\end{array}$ & International & Focus on medium to large scale mines & $\begin{array}{l}\text { "IRMA is establishing best practice standards that improve the environmental and social performance of } \\
\text { mining operations, as well as a system to independently verify compliance with those standards" [27]. }\end{array}$ \\
\hline $\begin{array}{l}\text { Aluminum stewardship } \\
\text { (Est. 2012) }\end{array}$ & $\begin{array}{l}\text { Run by International Union } \\
\text { for the Conservation of } \\
\text { Nature (IUCN) }\end{array}$ & $\begin{array}{l}\text { Has a focus on bauxite mining and } \\
\text { smelting industry (more than consumers) }\end{array}$ & $\begin{array}{l}\text { "The Aluminium Stewardship Initiative (ASI) was initiated in } 2012 \text { to foster greater sustainability and } \\
\text { transparency throughout our industry. Spearheaded by several industry players, the ASI is a non-profit initiative } \\
\text { that seeks to mobilise a broad base of stakeholders to establish and promote responsible leading practices, } \\
\text { across the aluminium value chain, in business ethics; environmental performance; social performance" [28]. }\end{array}$ \\
\hline
\end{tabular}


Large multinationals have significant power and are now imposing higher standards upon their external stakeholders. Multinational companies (MNCs) such as Dell are using SSCM assessment tools such as questionnaires and codes of conduct to assess suppliers on their environmental management. As an early mover in the field of sustainable practice, Fuji Xerox expects to benefit from active SSCM [29]. The eco-labeling of seafood products presents an example where numerous competing accreditation and reporting mechanisms have emerged at an industry level, although there is some debate as to the extent of the impact of these schemes on existing practices [30].

Investors are ranking companies on sustainability initiatives, and environmentally responsible investing is gaining popularity among the investor community. Organizations that have adopted sustainability initiatives throughout their supply chain are expected to show superior performance and favorable risk/return profiles [31].

Material prepared by the SSF sets out the reasons why sustainable procurement of steel is important in terms of business risks and opportunities associated with supply chain impacts of material choice. Risks include legal risk and health and safety issues associated with product failure. Opportunities include establishing customer loyalty through brand recognition [32].

Recent research seems to indicate that confusion around sustainability criteria and environmental issues impact on organizational procurement behavior [33]. Clarity of sustainability standards to accurately reflect environmental impacts, for example, appears to be necessary for more considered and strategic sustainable procurement. In the following section, we explore how collaboration across a supply network is assisting in clarifying sustainability standards in the steel industry in Australia and hence potentially, its strategic ability to compete in a global market.

\section{Case Study: SSF and Responsible Steel}

\subsection{Background to the Case}

We use a case study approach to explore the structures and processes that are assisting the steel industry in Australia to move towards stewardship across the steel supply chain. The case study method is suitable to exploratory research that concerns the dynamics of a particular contemporary phenomenon [34]. The steel industry in Australia is justified as a critical case study with which to examine structures and processes that underpin sustainability certification and a strategic approach to SSCM in metals for a number of reasons. Australia has the second largest accessible reserves of iron ore, which is a key input in the production of steel-hence the importance of ascertaining how SSCM can be realized in this industry. Steel has qualities that make it vital for infrastructure, is critical to the economy and is a one of the highest users of energy in the manufacturing sector [35-37]. Steel industry representatives in Australia claim a worldwide industry commitment to reduce energy and greenhouse gas emissions for both environmental and cost reasons and argue the "green virtues" of steel need to be communicated more effectively via tools such as rating systems and Life Cycle Analysis [38].

The principal structure involved in promoting the development of a certification scheme for steel in Australia is the SSF and hence the focus for our study. Data for the study was collected from a range of secondary documents, from the SSF website and from informal discussions with representatives of 
the SSF. The concept of the SSF emerged from discussions in association with Asia-Pacific Economic Cooperation (APEC) meetings during 2007. Key individuals within leading resources companies and consultancies engaged with product stewardship took up the opportunity to work with representatives from industry, government and NGOs towards developing a steel stewardship model that could be shared with APEC. The SSF was established in 2008 as a result of these discussions and has been meeting regularly and expanding its membership ever since. The stated purpose of SSF is "to maximize the value of steel to society, whilst minimising the negative commercial, social and environmental impact across the life cycle" [1].

The need for structures and processes that would enable a stewardship approach to steel in Australia is based in the fact that currently there is no mechanism across the steel supply chain to consistently and comprehensively capture, measure, benchmark and communicate efforts on climate change, environmental programs and other sustainability indicators. Efforts are sector association or company based at present rather than as an aggregated supply chain - in other words there are attempts being made to improve sustainability of the industry but as yet there are no widely adopted mechanisms at the total supply chain or network level. The lack of such a process to collectively improve the entire supply chain and communicate the current and future successes restricts the steel producer's ability to report on and improve its credentials in the market and with regulators [39]. At the time of formation of the SSF, it was seen as particularly important given major policy initiatives in Australia placing increasing pressure on supply chains, such as with energy efficiency as a result of the passing of the Energy Efficiency Opportunities Act 2006.

\subsection{Stakeholder Perceptions of the Steel Industry}

A key driver of the implementation of the SSF's sustainability initiative is the perception of key stakeholders that steel products are as much a part of the problem in relation to the environment as part of the solution. According to a World Steel Association survey conducted in 2009:

"Commenting on steel products as being part of the problem, solution or both, when considering the many challenges facing the environment globally, 52\% consider steel to be both a part of the problem and the solution. Steel is considered part of the solution by 25\% and part of the problem by the remaining $23 \%$ of respondents" [40].

The SSF body aims to develop steel stewardship across the entire steel supply chain within the Australian market and to act as a template or "best practice" model for the region. The SSF concept brings together representatives from all major sectors of the Australian steel product life cycle from mining through steel manufacturing, processing, product fabrication, use and re-use, and recycling. It links in different levels of government and the major Australian scientific research organization, Commonwealth Scientific Industrial Research Organisation (CSIRO). Engaged stakeholders now include more than 60 organizations, including two major banks, industry associations, NGOS as well as steel producers and miners. An important aspect of the SSF is that individuals representing different stakeholder groups across its member organizations have been nominated and allocated specific roles in terms of its operations. The Executive Committee, for example, consists of representatives from the steel solutions industry, industry associations and the minerals and mining sector. 
The focus of the SSF is to unite "key stakeholders along the steel product life cycle within a structured form" and to act as a hub enabling the sharing of practice and information in the area of environmental sustainability [25]. The SSF believe that, collectively, the steel industry can add value to and improve the performance of the steel industry across the whole product life cycle [39]. The SSF structure includes certain rules that are designed to assist in the development of appropriate governance mechanisms for the Forum. These include a Code of Conduct and Guidelines concerning activities to ensure they accord with anti-trust laws.

\subsection{Outcomes of the SSF}

The SSF is continuing to progress towards its aim of establishing the Responsible Steel scheme as a means of providing certification of compliance with nominated sustainability criteria for all sectors of the steel supply chain, covering the full life cycle of steel. It aims firstly to target the mining and steel manufacturing with the full supply chain to be covered within five years. Achievements to date include a pre-feasibility business case for Responsible Steel (Phase 1), leading into a detailed design phase (Phase 2).

In Phase 1, the SSF framed the discussion of the certification scheme around a set of eight program attributes that are common to successful certification schemes (Table 2).

Table 2. Program attributes of successful certification schemes.

\begin{tabular}{|c|c|c|}
\hline Number & $\begin{array}{c}\text { Responsible certification } \\
\text { scheme program attributes }\end{array}$ & Definition \\
\hline 1 & Independence & $\begin{array}{l}\text { Minimizing perceived conflicts of interest through independent } \\
\text { third party assessment }\end{array}$ \\
\hline 2 & Transparency & $\begin{array}{l}\text { Publicly disclosing certification criteria, how assessments are } \\
\text { carried out, and hidden trade-offs }\end{array}$ \\
\hline 3 & Clarity & $\begin{array}{l}\text { Minimizing customer and participant confusion by establishing } \\
\text { product assessment criteria which clearly differentiate preferable } \\
\text { products from others }\end{array}$ \\
\hline 4 & Traceability & $\begin{array}{l}\text { Implementing a chain-of-custody program to demonstrate the } \\
\text { link between program and sustainability results/outcomes }\end{array}$ \\
\hline 5 & Reassessment & $\begin{array}{l}\text { Scheduling reassessment within a predefined period to build trust } \\
\text { with participants and allow for factors such as new technologies, } \\
\text { new products, new environmental information and market } \\
\text { changes to be taken into account }\end{array}$ \\
\hline 6 & Leadership & $\begin{array}{l}\text { Establishing quantitative metrics for success and demonstrating } \\
\text { how the program is contributing to sustainable development }\end{array}$ \\
\hline 7 & Flexibility & $\begin{array}{l}\text { Accommodating participants of various sizes and place within } \\
\text { the steel value chain }\end{array}$ \\
\hline 8 & Stakeholder engagement & $\begin{array}{l}\text { Ensuring stakeholder participation and input on program } \\
\text { development and ongoing implementation }\end{array}$ \\
\hline
\end{tabular}

In Phase 2, detailed Design Principles for the certification scheme have been developed. For example, these Principles state that the Responsible Steel scheme: 
"shall first certify 'entities' along the steel supply chain, not the products. An entity can be a whole company, a part of a company, or a site and this will be clearly described in the certification. Once this system is operational with sufficient participation levels, a chain of custody system will then be launched where a product or product group can be certified" [41] (p. 2).

During this phase a comprehensive project plan and timeline has been established. A proposed structure for the Responsible Steel organization has been drafted. An Industry Advisory Panel has been established with 14 members and an External Advisory Panel with 18 members whose responsibility will be to assist with the development of the certification criteria.

Although some details of the scheme are yet to be decided, according to the Design Principles, the Responsible Steel scheme is expected to achieve the following outcomes [41] (p. 1):

- A structured, efficient and multi metric method for steel supply chain companies to communicate their company and product credentials to the public and market;

- Performance benchmarking, setting of improvement targets and monitoring of progress towards achieving targets;

- Member access to resources and networks to assist in improving performance, e.g., energy efficiency and profitability;

- Differentiation of certified participant companies and their products from others in the market;

- Savings in time, effort and money for the participants and their customers when they have to verify their sustainability attributes;

- Acceptance by specifiers and purchasers - seen as a valuable and differentiating requirement in specifying materials and suppliers for projects;

- An integral component of rating tools;

- Help certified participant companies to meet current and future demands for reliably audited sustainability credentials for their products.

Another project completed by SSF in preparation for making further progress with the Responsible Steel initiative was the Steel Chain Footprint [42]. This project was undertaken by the consulting firm Energetics Pty Ltd. (North Sydney, Australia) with the aim of establishing main commodity flows, inputs and outputs and emission intensities (rather than a detailed life cycle assessment). Data were provided by companies in their respective sections of the supply chain to establish flows using specific data templates tailored to: (i) mining; (ii) iron and steel making; (iii) applications and use. It was aggregated respecting commercial-in-confidence aspects of individual companies A full description of the methodology is available in their public report. Major energy uses are in steelmaking (rather than mining). Approximately one third of water is used in mining and two thirds in steel plate making [42]. The aim was to provide a picture of the life cycle of steel in Australia and assess the degree of data available with respect to flows and emissions as a baseline against which future performance criteria in certification could be referenced.

As a prerequisite to the development of the certification scheme, and as a means of facilitating communication across its members, the SSF directed a high level input/output mapping of the Australian steel chain to identify "areas of interest" and direct attention towards improvement solutions. It focused on mapping key materials and emissions. Most members of the SSF contributed data and the project was partly funded by SSF members and partly by state and federal government 
departments. Figure 2 contains a summary representation of the material flows within the steel supply chain produced as a result of this project. As shown in Figure 2, steel is made via two principal routes: (i) via a blast furnace to make iron, followed by basic oxygen steelmaking (BOS) to refine the iron into steel using iron ore and coal as the key raw materials; (ii) via an electric arc furnace (EAF) using iron from a blast furnace or scrap metal. Australia has two sites with blast furnace/BOS technology at Port Kembla (NSW) and Whyalla (SA) and three smaller EAF sites in Melbourne (VIC), Sydney (NSW) and Newcastle (NSW). Products are classified into three main groups of: (i) hot rolled long products, such as bars, beams, railway tracks; (ii) hot rolled coil including steel for roofing and buildings, appliances; (iii) hot rolled plate.

Further SSF funded projects focused on testing socio-environmental benefits associated with steel are also underway in collaboration with a SSF environmental NGO member Greening Australia, Michael Mobbs and Tankworks [43].

The ongoing implementation processes are expected to see Proof of Concept testing in 2015 and a live entity based scheme implemented in 2015/2016 [44].

\section{Discussion}

This case study highlights the importance of collaboration between the various stakeholders in the steel industry in moving toward a stewardship approach to their product across its life cycle. In returning to our question concerning the structures and processes that enable this collaboration it is useful to take an institutional approach to examine how the new "institution" of steel stewardship has been created [45]. Using this lens, we explore how the interactions between the various organizations in the SSF have normatively sanctioned various practices [46]. We see how collaboration across a network can generate a new shared norm around sustainability and that this has been facilitated through interactions between network members around the Responsible Certification scheme and associated mapping projects. The importance of the normative network structure thus formed through the establishment of the SSF is that it changed the relationships between the different members of the steel supply network.

In institutional theory terms, mimetic isomorphism is occurring as mimetic processes around SSCM are disseminated through the operations of the SSF, facilitated by both NGOs and government members. We also see the importance of institutional entrepreneurs in generating change, as individuals within organizations work to overcome boundaries between organizations and to create new institutions. These entrepreneurs "have an interest in particular institutional arrangements and who leverage resources to create new institutions or to transform existing ones" [47].

This entrepreneurship activity is evident initially as key individuals within industry associations and firms in the steel industry with an interest in product stewardship pushed for the establishment of the SSF. We see it continuing through the commitment of the SSF leadership in the Executive Committee. The multiple stakeholder structure of the SSF has enabled these entrepreneurs to work towards changing previously held norms and practices that have acted as barriers to collaboration and transparent communication. 
Figure 2. Australian steel material flows [48]. Reprinted/Reproduced with permission from 2012 Steel Stewardship Forum.

\section{Australian Steel Material} Flows 2007-2008

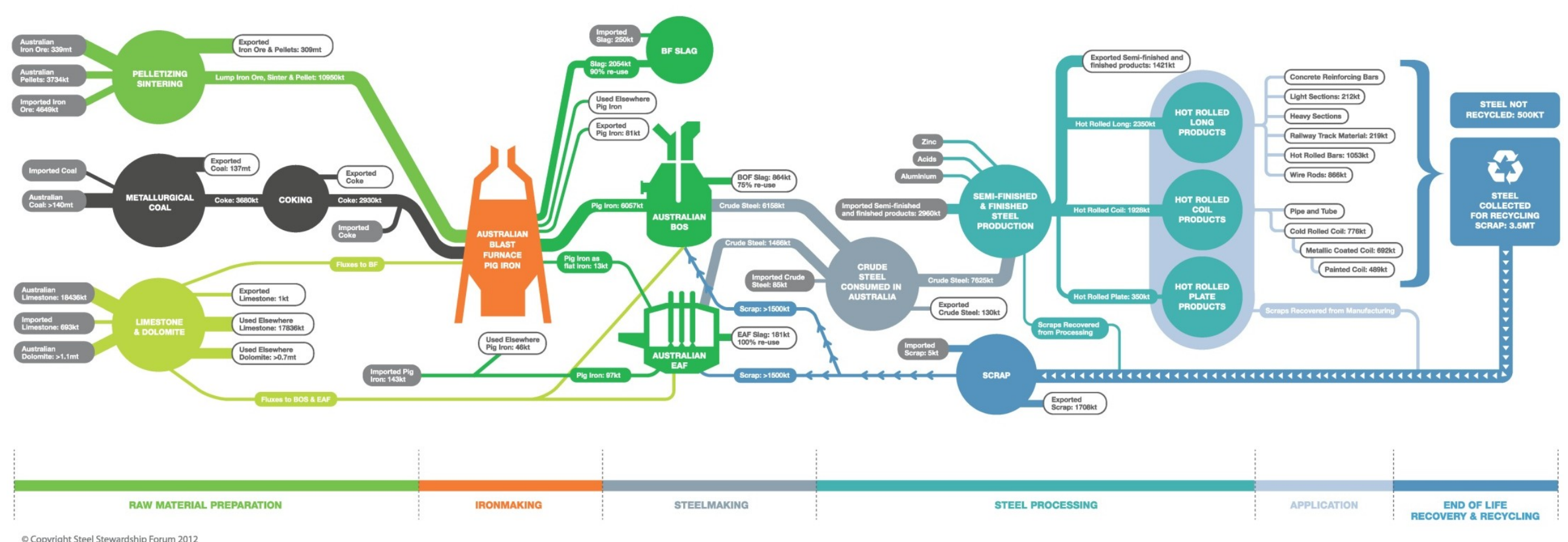


The study also highlights the role that inter-organizational collaboration can play in progressing the individual organization along the sustainability phase model. Going beyond the sharing of information to developing strategic insights into how sustainability can relate to planning and management has been facilitated through the network activities such as the Footprint and Certification exercises. Strategic sustainability implies differentiation through managing the reputational risks and opportunities around sustainability, specifically targeted through these exercises and legitimated through the SSF network.

Considering the future of the industry in Australia, other relevant factors include the high Australian dollar, and high costs for iron ore and coking coal inputs, making exports expensive and limiting profits. Whereas in 1995 approximately $80 \%$ of the profit in the steel value chain sat with steel makers (and little with iron ore miners and coking coal producers) in 2011, the largest share of the profit in the value chain goes to the iron ore miners (46\%) followed by coking coal $(28 \%)$ and then steel makers (26\%) [37]. In addition, scrap in Australia is largely melted down to be reused into low-grade products (such as reinforcing material for concrete). This would need to change if recycled share is to meet more of overall demand needs and would require better sorting and control of scrap quality used in EAF used to process scrap [49].

Whilst the SSF agenda represents a tangible step towards operating more sustainable steel industry in Australia, there are a number of challenges, which may influence the collective efficiency of the SSF strategy. As highlighted in the 2012 SSF Australian Steel Chain Footprint project, there is within and between firm variation across the industry as to what and how information is collected, and how it is stored; resulting in a range of data requiring imputed rather than measured information when assessing life cycle inputs and outputs. Given that SSF is a voluntary initiative, decisions about how information is collected are likely to be influenced by a range of firm level tradeoffs such as implementation costs, which may lead to variable levels of information quality continuing into the future. Competitive barriers may also need to be managed, as individual firms face information sharing barriers, such as on information, which is commercially sensitive or which may adversely affect an individual firm's reputation. The temptation is for industry benefiting choices to be traded off against firm level benefits. The level of adoption is likely to be influenced by whether the identifiable benefits or risks from inaction are understood and relevant to industry participants. This issue has been addressed to some extent by the SSF adopting overarching principles for information. The challenge is whether individual firms and supply chain partners are able to successfully implement comparable systems.

Another risk is that the certification scheme, which emerges out of the SSF, may not adequately capture all relevant sustainability factors, omitting critical information and technology-related control factors. The challenge for SSF is whether they are able to adequately support a certification scheme, which mitigates these challenges. In addition, the comparability of the information content and delivery mechanism championed by SSF to other standards is a critical issue, with steel being an input to a diverse range of supply chains. The challenge is exacerbated by the evolving global landscape of certification schemes. As the SSF progresses, it may be expected that the links between the SSF and other global forums, such as set out in Table 1, will allow for the SSF approach to co-evolve, hence contributing to a broader audience than only the Australian steel industry.

We acknowledge limitations to this exploratory study in that it relies on data obtained from secondary documentation. We recognize our case study would be enhanced by material from 
interviews with the SSF members and this is the intention for further research. We believe we have scoped the study and identified a suitable theoretical framework upon which to build in a future study.

\section{Conclusions}

This paper has demonstrated that appropriate structures, such as the SSF, and processes, such as the Footprint project implemented to promote stakeholder communication, might facilitate cooperation across the steel supply chain as a means of promoting SSCM. In more general terms, findings from the paper contribute to our understanding of the shift to SSCM as it is interpreted through institutional and institutional entrepreneurship theory. It has shown the importance of network based interaction around the development of new norms in the steel industry, with Australia's leading initiative geared to the development of a certification scheme for Responsible Steel having the potential to achieve competitive advantage as well as a more environmentally sustainable industry sector.

\section{Acknowledgments}

Some of this research was undertaken as part of the Wealth from Waste Research Cluster, a collaborative program between the Australian Commonwealth Scientific Industrial Research Organisation (CSIRO); University of Technology, Sydney; The University of Queensland, Swinburne University of Technology, Monash University and Yale. The authors gratefully acknowledge the contribution each partner and the CSIRO Flagship Collaboration Fund. The Wealth from Waste Research Cluster is a part of the Minerals Down Under National Research Flagship and is supported by the Future Manufacturing National Research Flagship.

\section{Conflicts of Interest}

The authors Suzanne Benn, Paul Brown and Renu Agarwal declare no conflict of interest. Damien Giurco serves on the external advisory panel of the Steel Stewardship Forum.

\section{References}

1. Steel Stewardship Forum (SSF). Responsible Steel. Available online: http://steelstewardship.com/ projects/responsible-steel/ (accessed on 12 January 2014).

2. Reducing Risk and Driving Business Value; Carbon Disclosure Project (CDP) Supply Chain Report; CDP: New York, NY, USA; 2012-2013. Available online: https:/www.cdproject.net/CDPResults/ CDP-Supply-Chain-Report-2013.pdf (accessed on 12 January 2014).

3. Zhu, Q.; Sarkis, J. Relationships between operational practices and performance among early adopters of green supply chain management practices in Chinese manufacturing enterprises. $J$. Oper. Manag. 2004, 22, 265-289.

4. Seuring, S.; Sarkis, J.; Müller, M.; Rao, P. Sustainability and supply chain management-An introduction to the special issue. J. Clean. Prod. 2008, 16, 1545-1551.

5. Seuring, S.; Müller, M. From a literature review to a conceptual framework for sustainable supply chain management. J. Clean. Prod. 2008, 16, 1699-1710. 
6. Kolk, A.; Mauser, A. The evolution of environmental management: From stage models to performance evaluation. Bus. Strateg. Environ. 2002, 11, 14-31.

7. Welford, R.; Gouldson, A. Environmental Management \& Business Strategy; Pitman Publishing Limited: London, UK, 1993; p. 210.

8. Nattrass, B.F.; Altomare, M. The Natural Step for Business: Wealth, Ecology and the Evolutionary Corporation; New Society Publishers: Gabriola Island, Canada, 1999; p. 222.

9. Roome, N. Developing environmental management strategies. Bus. Strateg. Environ. 1992, 1, 11-24.

10. Dunphy, D.; Griffiths, A.; Benn, S. Organizational Change for Corporate Sustainability, 2nd ed.; Routledge: London, UK, 2007; p. 346.

11. Benn, S.; Dunphy, D.; Griffiths, A. Organizational Change for Corporate Sustainability, 3rd ed.; Routledge: London, UK, 2014, in press; p. 348.

12. Young, S.B.; Fonseca, A.; Dias, G. Principles for responsible metals supply to electronics. Soc. Responsib. J. 2010, 6, 126-142.

13. Nest, M. Investing in Africa: Politics, Conflict Minerals and China. In Proceedings of the AuslMM Sydney Branch February Technical Meeting, Sydney, Australia, 20 February 2013.

14. Vanclay, F.; Esteves, A.M. Current Issues and Trends in Social Impact Assessment. In New Directions in Social Impact Assessment: Conceptual and Methodological Advances; Edward Elgar Publishing: Cheltenham, UK; Northampton, MA, USA, 2011; pp. 3-19.

15. Seay, L. What's Wrong with Dodd-Frank 1502? Conflict Minerals, Civilian Livelihoods, and the Unintended Consequences of Western Advocacy; Center for Global Development Working Paper No. 284; Center for Global Development: Washington, DC, USA, 5 January 2012.

16. Rainey, D.L. Sustainable Business Development: Inventing the Future through Strategy, Innovation, and Leadership; Cambridge University Press: Cambridge, UK, 2006; p. 764.

17. Green, K.; Morton, B.; New, S. Greening Organizations: Purchasing, Consumption, and Innovation. Organ. Environ. 2000, 13, 206-225.

18. Tarantini, M.; Loprieno, A.D.; Porta, P.L. A life cycle approach to Green Public Procurement of building materials and elements: A case study on windows. Energy 2011, 36, 2473-2482.

19. Lee, H.L. Don't tweak your supply chain—Rethink it end to end. Harv. Bus. Rev. 2010, 88, 62-69.

20. Giurco, D.; McLellan, B.; Franks, D.; Nansai, K.; Prior, T. Responsible mineral and energy futures: Global perspectives. J. Clean. Prod. 2014, submitted for publication.

21. Dodd-Frank Wall Street Reform and Consumer Protection Act; Public Law 111-203; 111th Congress; United States Congress: Washington, DC, USA, 21 July 2010.

22. Conflict Free Minerals. Available online: http://www.conflictfreesmelter.org/documents/ Conflict-FreeSmelterFAQ.pdf (accessed on 12 February 2014).

23. Alliance for Responsible Mining. Available online: http://www.communitymining.org/en (accessed on 15 January 2014).

24. Earthworks' No Dirty Gold. Available online: http://nodirtygold.earthworksaction.org/ (accessed on 12 January 2014).

25. Steel Stewardship Forum (SSF). Responsible Steel, Rules. Available online: http://steelstewardship.com/about-us/rules/ (accessed on 16 January 2014).

26. Responsible Jewellery Council. Available online: http://www.responsiblejewellery.com/ (accessed on 12 January 2014). 
27. Initiative for Responsible Mining Asssurance. Available online: http://www.responsiblemining.net/ (accessed on 12 January 2014).

28. Aluminium Stewardship Initiative. Available online: http://aluminium-stewardship.org/ (accessed on 12 January 2014).

29. Fuji Xerox Australia Sustainability. Eco Manufacturing Centre. Available online: http://www.fxasustainability.com.au/eco_about.php (accessed on 12 January 2014).

30. Thrane, M.; Ziegler, R.; Sonesson, U. Eco-labelling of wild-caught seafood products. J. Clean. Prod. 2009, 17, 416-423.

31. The Sustainability Yearbook 2014; RobecoSAM: Zurich, Switzerland, January 2014. Available online: http://www.sustainability-indices.com/images/sustainability-yearbook-2014_ tcm1071-380153.pdf (accessed on 13 Feburary 2014).

32. Davies, R. Where You Buy from Matters? Available online: http://steelstewardship.com/ (accessed on 12 January 2014).

33. Polonsky, M.J.; Vocino, A.; Grau, S.L.; Garma, R.; Ferdous, A.S. The impact of general and carbon-related environmental knowledge on attitudes and behaviour of US consumers. J. Mark. Manag. 2012, 28, 238-263.

34. Yin, R.K. Applications of Case Study Research, 3rd ed.; SAGE Publications, Inc.: Thousand Oaks, CA, USA, 2011; p. 264.

35. McLellan, B.C.; Corder, G.D.; Giurco, D.P.; Ishihara, K.N. Renewable energy in the minerals industry: A review of global potential. J. Clean. Prod. 2012, 32, 32-44.

36. World Energy Outlook 2011; International Energy Agency (IEA): Paris, France, 2011; p. 666.

37. World Steel Association. The Future of the Global Steel Industry-Challenges and Opportunities. In Proceedings of the IMnl 39th Annual Conference, Istanbul, Turkey, 4-6 June 2013.

38. Australian Steel Institute. Touching the Earth Lightly-Australian Steel's Role in a Sustainable World. Available online: http://steel.org.au/key-issues/sustainability (accessed on 15 January 2014).

39. PE Australia Pty Ltd. Responsible Steel: Business Plan; Steel Stewardship Forum (SSF): South Perth, Australia, June 2012.

40. World Steel Association. Stakeholder Survey. Available online: http://www.worldsteel.org/steelby-topic/sustainable-steel/stakeholder-survey.html (accessed on 18 November 2013).

41. Steel Stewardship Forum (SSF). Responsible Steel Stewardship_Phase 2 Design Development Design Principles. Available online: http://steelstewardship.com/media/File/Resp_Steel_Design_ Principles_FINAL_15Aug13.pdf (accessed on 3 March 2014).

42. Australian Steel Chain Footprint Project; Steel Stewardship Forum (SSF) Report Prepared by Energetics Pty Ltd: North Sydney, Australia, May 2012. Available online: http://steelstewardship.com/media/File/SSF_Australian_Steel_Chain_Footprint_FINAL_v402.pdf (accessed on 12 Februry 2014).

43. Steel Stewardship Forum (SSF). Socio-Economic Initiatives. Available online: http://steelstewardship.com/projects/socio-economic-initiatives/ (accessed on 12 January 2014).

44. Davies, R. Materials Stewardship. Presented at University of Technology, Sydney, Sydney, Australia, 5 September 2013. 
45. Grob, S.; Benn, S. An institutional approach to sustainable procurement. Australas. J. Environ. Manag. 2014, in press.

46. Lawrence, T.; Suddaby, R. Institutions and Institutional Work. In The Sage Handbook of Organizational Studies, 2nd ed.; Clegg, S., Hardy, C., Lawrence, T., Nord, W., Eds.; Sage: London, UK, 2006; pp. 214-254.

47. Maguire, S.; Hardy, C.; Lawrence, T.B. Institutional entrepreneurship in emerging fields: HIV/AIDS treatment advocacy in Canada. Acad. Manag. J. 2004, 47, 657-679.

48. Steel Stewardship Forum (SSF). Australia's Steel Value Chain. Available online: http://steelstewardship.com/media/File/Steel_Chain_Footprint_Brochure_Final.pdf (accessed on 3 March 2014).

49. Brooks, G.; Pan, Y. Developments in Steel Recycling Technology. In Green Processing; AusIMM: Freemantle, Australia, 2004; pp. 65-72.

(C) 2014 by the authors; licensee MDPI, Basel, Switzerland. This article is an open access article distributed under the terms and conditions of the Creative Commons Attribution license (http://creativecommons.org/licenses/by/3.0/). 